University of Nebraska - Lincoln

DigitalCommons@University of Nebraska - Lincoln

Faculty Publications: Political Science

Political Science, Department of

2007

\title{
Personal, Interpersonal, and Political Temperaments
}

John Alford

Rice University in Houston

John R. Hibbing

University of Nebraska-Lincoln, jhibbing1@unl.edu

Follow this and additional works at: https://digitalcommons.unl.edu/poliscifacpub

Part of the Political Science Commons

Alford, John and Hibbing, John R., "Personal, Interpersonal, and Political Temperaments" (2007). Faculty Publications: Political Science. 29.

https://digitalcommons.unl.edu/poliscifacpub/29

This Article is brought to you for free and open access by the Political Science, Department of at DigitalCommons@University of Nebraska - Lincoln. It has been accepted for inclusion in Faculty Publications: Political Science by an authorized administrator of DigitalCommons@University of Nebraska - Lincoln. 


\section{Personal,}

\section{Interpersonal,}

\section{and Political}

\section{Temperaments}

\author{
John R. Alford \\ and \\ John R. Hibbing
}

Published in The ANNALS of the American Academy of Political and Social Science 614 (2007), pp. 196212; doi 10.1177/0002716207305621 Copyright (C) 2007 American Academy of Political and Social Science; published by Sage Publications. Used by permission. http://ann. sagepub.com/cgi/content/abstract/614/1/196

\begin{abstract}
Are political liberals generous? Are political conservatives conscientious? Are generous people personally agreeable? Research in behavioral genetics and elsewhere increasingly indicates a biological basis for the manner in which people behave in personal, interpersonal, and political situations, but this biological basis does not mean behavior in these three very different contexts is correlated. In this article, using an original data set obtained from nearly three hundred subjects, the authors are able to test for the degree to which personal, interpersonal, and political temperaments are related. As expected, the overall correlations are quite low. Standard personality traits do not predict political attitudes, and neither political attitudes nor personality predicts the extent to which subjects are generous in interpersonal situations. Human behavior is partially biological, but the systems involved in shaping political behavior seem to be largely but not completely distinct from those involved in shaping personal and interpersonal behavior.
\end{abstract}

Keywords: temperament, political attitude, personality traits, behavior, ideology

$\mathrm{T}$ he study of personality remains a controversial subfield in psychology, and it is doubtful there will ever be universal agreement on its essential component parts. The five- factor model-extroversion, agreeableness, conscientiousness, neuroticism (sometimes called emotional stability), and intellect/ imagination (sometimes called openness) - is increasingly believed to capture the essence of personality (McCrae and Costa 1999; DeYoung, Peterson, and Higgins 2005; Mondak and Halperin forthcoming), but other personal temperaments such as risk-taking and harm avoidance are also frequently invoked. Still other constructs such as right-wing authoritarianism and social dominance orientation fight for recognition along with numerous other alleged dimensions; the overall result is a conceptual mishmash. Some observers would say this confusion is unavoidable given the com- 
plexities of the human condition, but we think progress can be made by recognizing that not all predispositions are best thought of as stemming from personal temperament. In this article, we argue and provide empirical evidence that the behaviors of an individual are not influenced solely by the personal temperaments traditionally studied by psychologists but also by reasonably distinct interpersonal and political temperaments that operate alongside personal temperament.

\section{Distinguishing the Personal from the Interpersonal and the Political}

Conceptually, personal temperament is quite different from interpersonal temperament, and interpersonal temperament, in turn, is quite distinct from political temperament. Personal temperament does not require other people to be in evidence. Risk-taking could manifest itself while an individual climbs a tree far from any other person (though it could also be in evidence in interactions with other people). Interpersonal temperament by definition requires another person. It is impossible to know whether a person is generous, trusting, or punitive unless other individuals are involved. But modern society has given rise to a third temperament, namely, political temperament. Like interpersonal, political temperament requires other people; unlike interpersonal, political temperament operates on a mass scale. Interpersonal involves those in the immediate social unit-fellow players in an economic game, office mates at work, or relatives at a family reunion. Political temperament, on the other hand, deals with the structure and organization of large-scale social life. The issues shift from whether a person nearby should be punished for being self-serving to whether in general it is preferable for misbehaving individuals to be punished and whether that punishment should be severe and automatic or mild and flexible. Politics involves the norms, mores, and statutes that govern large-scale social life, norms and statutes that do not only apply to people well known and close by but also to people unknown and far away.

\footnotetext{
John R. Alford is an associate professor of political science at Rice University in Houston, Texas. He has been published in the American Political Science Review, the American Journal of Political Science, and Perspectives on Politics. His work addresses congressional elections, political parties, and, most recently, the influence of biological variables, including genetics, on political orientations and behaviors.

John R. Hibbing is the Foundation Regents University Professor of Political Science at the University of Nebraska-Lincoln. With Elizabeth Theiss-Morse, he is the author of Congress as Public Enemy as well as Stealth Democracy, both dealing with public attitudes toward government, governors, and governing. His recent work, primarily with John Alford but also with Kevin Smith and others, attempts to integrate biological concepts and the social sciences. Financial support provided by the National Science Foundation (SES350387). This article was written during a time when both authors were visiting fellows at the Hoover Institution, Stanford University, Stanford, California. The authors thank David Brady and others at Hoover for their hospitality.
} 
The term politics is frequently used to refer to maneuvering in the immediate social environment. De Waal $(1982,1996)$ pointed out that primate troops can be seen playing politics of this type; humans will often write off unfavorable decisions at work or elsewhere as being shaped by "politics." Despite this common usage, we suggest that politics at the mass level can be distinguished from the interpersonal machinations that are often referred to as political. Thus, for our purposes, personal temperaments are predispositions (fastidiousness, for example) that can manifest themselves even when other people are not present. Interpersonal temperaments (being generous, for example) are at least dyadic in that they involve at a minimum one person in the immediate social environment. And political temperaments are those that apply to the governance of large-scale social life, life that extends beyond one's immediate social environment.

Whereas personal temperament has been studied mainly by psychologists and political temperament mainly by political scientists, interpersonal temperament is of interest to social psychologists as well as to sociologists and behavioral economists. Personal and political temperaments are usually assessed by survey questions, while for interpersonal temperament, experiments are often employed to determine the extent to which people share with others, trust others, and punish those who have behave selfishly. Trust, generosity, and interpersonal sanctioning are inherently social; as such they are distinct from risk taking or paranoia as well as from liberal or conservative political attitudes.

But are these three temperaments empirically as well as conceptually distinct? Our operating hypothesis is that they are largely but perhaps not completely uncorrelated, that individuals' preferences for the conduct of their personal lives are only weakly predictive of their preferences for both largescale societal organization and behaviors in concrete, small-scale social situations. Casual observation would seem to support this hypothesis. When Rush Limbaugh was found to be addicted to drugs, his vast radio audience did not desert him even though his behavior seemed inconsistent with his political arguments in favor of personal responsibility and harsh punishment of lawbreakers. His behavioral lapse was viewed as a personal indiscretion. But if he began condoning permissiveness and forgiveness as a political philosophy, his audience quite likely would evaporate quickly. While political liberals may take this as evidence of hypocrisy on the right, the truth of the matter is that those on the left also separate the political from the personal (and the interpersonal). The real message is that people's personal behaviors are quite different from the behaviors they advocate for society as a whole. The contention that the personal, interpersonal, and political are reasonably separate receives support from neuroscience studies indicating that the neural systems involved with basic personal emotions such as anger, frustration, joy, and excitement are quite different from the neural systems involved in emotions that cannot exist except in the context of other people, such as guilt, shame, and embarrassment. Our suspicion is that politics, at least in part, may tap into yet another neural system. 


\section{[P]eople's personal behaviors are quite \\ different from the behaviors they advocate for \\ society as a whole.}

Though we believe there is support for our expectation of relative independence across the temperaments, other expectations are possible. Perhaps interpersonal and political temperaments are merely spin-offs of personal temperament. Or perhaps the political is easily predicted from the interpersonal. The purpose of this article is to determine the extent to which these three core temperaments are related to each other. This is an important issue because if the personal is predictive of the political (and also the interpersonal), understanding personal temperament is all that is necessary for the understanding of interpersonal. Political behavior and the other social sciences would therefore become a subfield of psychology. But to the extent that political and interpersonal temperaments do not correlate with personal temperament, these areas of study must be undertaken with separate approaches, theories, and expectations. This situation becomes especially important for those interested in identifying the biological systems pertinent to temperaments and behaviors. Much is known about the genetic and biological precursors of personal temperament (see van Gestel and van Broeckhoven 2003; Comings et al. 2000; Bouchard and McGue 2003; Bachner-Melman et al. 2005; Carmen 2007 [this volume]), but little is known about the extent to which this information also informs us of the genes and biological systems pertinent to interpersonal and political temperaments. Thus, information on the overlap of personal, interpersonal, and political phenotypes is loaded with implications for our understanding of human behavior as well as for identifying the best methods for studying that behavior.

\section{Previous Research on the Connection of the Three Different Temperaments}

Given our formulation of three categories of temperaments, we can make three possible links among these categories: the link between the personal and the political, the link between the personal and the interpersonal, and the link between the interpersonal and the political. Previous research has looked into each of these links, although not always as intensely as the topic deserves and with a surprising amount of variance in the answers obtained. We take each of the links in turn. 


\section{Personal temperament and political temperament}

Of the three links, this is the one that has been analyzed the most. Academics have long suspected that particular personal temperaments may be the reason some individuals are, for example, politically conservative. Adorno et al.'s (1950) assertion that there is an "authoritarian personality" is perhaps the bestknown early attempt to link personal and political temperaments. The claim is that people who prefer to live their own lives in an authoritarian fashion also prefer authoritarian political arrangements; that some people have a need for structure, hierarchy, and clarity; and that this need is manifested in all aspects of their lives from personal to political. Altemeyer $(1981,1996)$ extended these ideas, suggested measurement changes, and termed it "right-wing authoritarianism," much to the consternation of those who believe hierarchy and structure are advocated as much by those on the political left as the political right (think Lenin; for an example of such a critique, see Shils 1954).

McClosky $(1958,28)$ also asserted that there is a "conservative personality," that conservatism is a position "around which individuals of certain habitual outlooks, temperaments, and sensibilities can comfortably come to rest and be united with others of like disposition." And the temperaments and dispositions McClosky found to be associated with conservatism are not particularly desirable. His data led him to conclude that conservatism is typically the philosophy of "social isolates, of people who think poorly of themselves, who suffer personal disgruntlement and frustration, who are submissive, timid, and wanting in confidence, who lack a clear sense of direction and purpose, who are uncertain about their values, and who are generally bewildered by the alarming task of having to thread their way through a society which seems to them too complex to fathom" (p. 37).

More recent research continues to identify the personality traits of conservatism - usually unfavorable traits. Using an imaginative research design, Block and Block (2005) reported that personality traits of nursery school children are predictive of political beliefs held by those same individuals when grown up. According to these findings, as children, adult conservatives tend to be "easily offended, indecisive, fearful, rigid, inhibited, and relatively over-controlled and vulnerable"; while children who go on to become adult liberals are "self-reliant, energetic, somewhat dominating, relatively under-controlled, and resilient" (p. 1). The modern consensus seems to be that conservatism is the result of a "motivated social cognition," in other words, a view of the social world that springs from a psychic need - in this case a need "to reduce fear, anxiety, and uncertainty; to avoid change, disruption, and ambiguity" (Jost et al. 2003, 340; see also Jost 2006).

The relative lack of attention to the personality bases of liberalism is potentially instructive in that it suggests that for many researchers, conservatism is the aberration in need of explanation: the normal human condition is political liberalism, and those who do not subscribe to it must possess unfortunate and lamentable personality traits such as "psychological rigidity" (McClosky 1958, 42) or runaway "anxiety and uncertainty" (Jost et al. 2003, 340), a need for authority (Altemeyer 1981, 1996; Lakoff 2006), or a need for their group to be bet- 
ter than others (Pratto et al. 1994). Thus, there is a need to explain what is the matter with Kansas (Frank 2004) but not to explain what is the matter with, say, Massachusetts. Of course, conservatives and others have been quick to challenge many of the findings summarized above. And indeed it seems that prominent exemplars of American conservatism today, such as Rush Limbaugh, Sean Hanity, Newt Gingrich, and Donald Rumsfeld, are not accurately characterized as "submissive, timid, and wanting in confidence"; lacking "a clear sense of direction and purpose"; and being "uncertain about their values."

When research is restricted to those personality traits psychologists tend to identify as central - for example, the "Big Five" of extroversion, agreeableness, conscientiousness, emotional stability, and intellect/intelligence-results are less clear. Using an American sample, Mehrabian (1996) found that four of the five core personality traits are not significantly related to political ideology, and the fifth, intellect/imagination, is related to conservatism at only -.26 (see also Comrey and Newmeyer 1965). Caprara's (Caprara, Barbaranelli, and Zimbardo 1999; Caprara et al. 2006) large Italian sample shows a somewhat stronger relationship than this, with conservatives scoring significantly higher than liberals on the extroversion and conscientiousness factors and (like Mehrabian 1996) significantly lower on imagination. Mondak and Halperin (forthcoming) found self- reported conservatism to be negatively related to imagination/openness and positively related to both conscientiousness and emotional stability (see Whitaker [2006] for additional evidence of links between the Big Five personality traits and political views).

All told, empirical results on this matter therefore are somewhat inconsistent. Not only are individual relationships found to be significant in some instances and insignificant in others, but the direction of significant relationships is sometimes positive and sometimes negative. It is disconcerting, for example, that conservatives are in some studies found to be "submissive, timid, and wanting in confidence" and in other studies to be extroverted. Part of the problem may be the different manners of conceptualizing personality. Many psychologists prefer purer personal temperaments such as the Big Five, but others branch out to hybrid concepts such as right-wing authoritarianism and social dominance orientation. As noted by critics (see, for example, Ray 1985), several of the items used to tap these latter concepts seem to draw on political attitudes, suggesting that relationships ostensibly between personality traits and political views are actually relationships between political views and other political views.

For example, two of the commonly employed social dominance orientation items are "in getting what you want it is sometimes necessary to use force against other groups" and "we should strive to make income as equal as possible." And two of the right-wing authoritarianism items suggested by Altemeyer $(1981,1996)$ are "gays and lesbians are just as healthy and moral as anybody else" and "God's laws about abortion, pornography, and marriage must be strictly followed before it is too late." None of these four seems to directly tap a core personality trait; rather, all four seem to come closer to tapping political and social attitudes. Thus, any correlation be- 
tween indices built on items such as social dominance orientation and rightwing authoritarianism on one hand and indices of political orientations on the other is conceptually suspect in the minds of many. To a certain degree, confusion on this matter is indicative of larger confusion on the separation between the personal and the political, an issue to which we hope to return later in this article.

\section{All told, empirical results ... are \\ somewhat inconsistent. ... It is disconcerting, for example, that conservatives are in some studies found to be "submissive, timid, and wanting in confidence" and in other studies}

to be extroverted.

\section{Personal temperament and interpersonal temperament}

Less work has been done on the relationship between interpersonal (or social) temperament and personal temperament. Most of the research in this area measures interpersonal behavior by decisions made in laboratory games involving small sums of money. These games include the dictator game, in which one player (the dictator) is free to divide a sum of money with another player however the dictator sees fit; the ultimatum game, in which, in contrast to the dictator game, the receiving player now has the option of accepting or rejecting the allocator's proposal; the trust game, in which the money a player sends to the other player is tripled but then is placed entirely under the discretion of the receiving (trusted) player; and the Prisoner's Dilemma, in which cooperative play is rewarded assuming the other player cooperates as well. Thus, measures of interpersonal generosity, punitiveness, trust, and cooperation are possible. Personal temperaments are measured by a variety of diverse schemes from the Eysenck Personality Quotient to Myers-Briggs to type A/sensation-seeking/selfmonitoring/ locus of control categories.

The results of these studies are as diverse as the approaches. Boone, De Branbander, and van Witteloostuijn (1999) found people with an internal locus of control, those with high self-monitoring, and those high in sensation seeking all tend to be slightly more likely to display cooperative behavior, particularly in multiple play games. Brandstatter and Guth (2002) conducted similar studies with a broader range of economic games, but the 
personality inventories they employed are more limited. They discovered that subjects claiming to be benevolent are more generous in dictator games (where the other player has no power) than they are in ultimatum games (where the other player can at least veto the proposal), but for the most part, the link to core personality traits is either untested or found to be absent. Finally, Swope et al. (2005), using the Myers- Briggs set of personality indicators, found no direct effects of any of the four categories of personality (orientation, perception, judgment, and attitude) on economic behavior, though they did find a small effect of personality on economic game play when the extroversion/introversion spectrum (orientation) is interacted with the feeling/thinking (judgment) spectrum. Individuals who are extroverted and tend to use feeling rather than thinking in their judgments are more cooperative in economic games.

\section{Interpersonal temperament and political temperament}

The connection between interpersonal behavior and political attitudes has likewise been the subject of less previous research than the possible connection between personal temperament and political temperament, and here again, the results suggest there may not be much of a connection. Early work by Mestelman and Feeny (1988) found suggestive evidence that, compared to liberals, conservatives are slightly more likely to free ride in a public goods game. (The public goods game has more than two players, and each player has the choice of contributing to a public fund or keeping their allotment. Money contributed to the public fund is multiplied but distributed back to all participants whether they contributed or not, so the optimal strategy from a selfish point of view is not to contribute but to take advantage of those who do contribute.) Using a German sample, Fehr et al. (2002) found a weak connection between party affiliation (but not ideological position) and trusting behavior.

And in perhaps the study most directly relevant to ours, Anderson, Mellor, and Milyo (2004), also using a public goods game, found "no significant differences in contribution for any one group of subjects" (Democrats, Republicans, liberals, or conservatives). These same scholars employed a trust game and (except for one special situation) reported similarly weak results across the various political groups. Their overall conclusion is that, contrary to conventional wisdom, liberals are not more likely to "play nice" than conservatives. All in all, a connection between political temperament and interpersonal temperament is not usually in evidence in these experimental studies.

Like the purported link between personal temperament and political temperament and the link between personal and interpersonal temperaments, this third possible link is found to be empirically weak. Previous research is quite inconsistent in findings, but one thing that can be said with some certainty is that neither the personal, the interpersonal, nor the political determines the other components. The human condition seems to be quite com- 
partmentalized depending upon the context in which decisions are made. But the varying results from these previous studies as well as the fact that all studies focus on just two of the temperaments rather than all three encourage us to collect our own original data and to perform our own analyses.

\section{Research Design}

In this article, we take advantage of a unique data set that contains information on each subject's personal, interpersonal, and political temperaments, thus making it possible to tie together the whole package. The 299 subjects were a combination of Rice University students and other nonstudent subjects recruited from the Houston metropolitan area. Each was asked an extensive array of personality items, including batteries tapping the Big Five. They were asked a set of political items, including the Wilson-Patterson Inventory of political and social attitudes, party identification, and self-identified ideology. And they were asked to play a series of economic games in which they had to make decisions including whether to be generous and whether to be punitive. The results for each type of temperament individually are of interest, but our primary concern here is with the correlations across temperaments, from personal to interpersonal to political. We want to clarify the uncertainty present in previous research and to determine whether our overarching hypothesis (a negligible relationship across temperaments) is correct.

\section{Findings}

Table 1 provides correlations for the Big Five personality factors, self-interest versus generosity in experimental games, and the two measures of ideology described above. Not all of the subjects participated in the same set of economic games; our experimental measure of behavioral generosity comes from combining two distinct pools of subjects. The larger group of 211 was given a choice of how much money to withdraw from a common pool of funds and could choose any amount from $\$ 0$ to $\$ 10$. The modal choice was $\$ 5$ with a second, less prominent peak at $\$ 10$. The remaining 88 subjects were dividing $\$ 10$ with another player in an ultimatum game where their choice was how much of the $\$ 10$ to keep for themselves and how much to give to the other player. Again, as in the common pool withdrawal, the modal choice was to retain $\$ 5$ with a second, much smaller peak at retaining $\$ 10$. In the table we provide both the results divided by game type and the combined dollar score for both groups. Clearly, there is little evidence of any direct connection between personality and behavioral generosity. Pool withdrawal is modestly correlated with two of the Big Five personality measures, negatively with conscientiousness (with individuals scoring higher on conscientiousness withdrawing modestly fewer dollars) 
Table 1. Personality, Interpersonal Economic Choices, and Ideology

\begin{tabular}{lccccc}
\hline & \multicolumn{5}{c}{ Self-Interest } \\
\cline { 2 - 6 } & $\begin{array}{c}\text { Pool } \\
\text { Withdrawal }\end{array}$ & Ultimatum & Combined & Ideology Wilson-Patterson \\
(Self-ID) & Index \\
\hline Big Five & & & & & \\
1. Extroversion & -.024 & .012 & -.120 & -.097 & -.086 \\
2. Agreeableness & -.093 & -.006 & -.074 & $-.153^{*}$ & $-.116^{*}$ \\
3. Conscientiousness & $-.140^{*}$ & .057 & -.088 & .012 & .082 \\
4. Emotional stability & -.008 & .181 & .026 & -.021 & .010 \\
5. Intellect/imagination & $.153^{*}$ & .015 & $.126^{*}$ & $-.136^{*}$ & $-.133^{*}$ \\
Ideology (self-ID) & -.051 & -.031 & -.053 & & \\
Wilson-Patterson index & -.051 & -.018 & -.053 & $.721^{*}$ & \\
$n$ & 211 & 88 & 299 & 299 & 299 \\
\hline
\end{tabular}

* Significant at the .05 level.

and positively with intellect (with individuals scoring higher on intellect/ imagination withdrawing slightly more dollars). Self-interest in the ultimatum game is very weakly related to the Big Five dimensions, and none of the correlations reaches statistical significance. When the two measures are combined, interpersonal self-interest is significantly related only to dimension five (intellect/imagination) where the modest positive relationship of intellect with selfishness is statistically significant.

Political ideology fares even worse. While consistently negative, indicating that higher levels of self-interest are associated with liberalism, the correlations for both self-described ideology and the Wilson-Patterson issuebased measure of ideology are small and fail to reach statistical significance. The correlation of personality traits with political ideology is a little more promising but still weak on the whole. Consistent with most all previous research, we find a negative relationship between intellect/imagination and ideological conservatism. Inconsistent with some previous research, we find no link between either conscientiousness or emotional stability and conservatism and we do find a negative relationship between agreeableness and conservatism.

One possible explanation for the general weakness of the correlations between personality and ideology is the presence of a nonlinear relationship. A particular personality factor, for example high intelligence, might be characteristic of both highly liberal and highly conservative individuals while generally less characteristic of moderates. Such a U-shaped relationship would be an example of a clearly predictive role for a personality factor but would nonetheless produce the sort of attenuated correlations that we see here. Exploring this possibility by fitting a variety of nonlinear models to the association between personality factors and ideology did not produce significant evidence of any sort of nonlinear relationship. Thus, the generally weak association between per- 
sonality and directional ideology is matched by little association between personality and nondirectional intensity of ideological sentiment.

The Wilson-Patterson Inventory is a useful addition to self-described ideology in part because it allows a more fine-grained analysis of how personality factors might affect distinct subcategories of ideology and even individual issue positions. Table 2 provides the correlations between the previously discussed five personality factors and the thirty items that make up the version of the Wilson-Patterson Inventory used here.

None of the thirty individual items is significantly related to more than three of the Big Five factors, and in fact only one of the thirty (foreign aid) is significantly related to three factors. A little more than a third of the individual items exhibit no significant relationship to any of the Big Five personality factors. And this group includes such high-profile items as abortion, gay rights, capitalism, pacifism, nuclear power, living together, school prayer, and mercy killing. This is striking not only because many of these are viewed as deeply emotional hot-button issues but also in light of the association of many of these issues with fundamental personal traits such as religiosity and the fact that several of these are among the most genetically heritable items in the Wilson-Patterson Inventory. Clearly people's strong emotional reactions to these items stem at least in part from very deep sources, but the standard Big Five model of personality is not tapping any of this variation.

Viewing the table down the columns is also informative. Factors 3 and 4 (conscientiousness and emotional stability, respectively) are notably weak predictors of individual issue positions with only three significant correlations in their collective sixty potential relationships, precisely what we would expect simply by chance at the .05 level of significance. Factor 2 (agreeableness) provides the most evidence of association with individual issue items, showing a significant relationship with thirteen of the thirty Wilson-Patterson issues. Higher levels of agreeableness are associated with opposition to the death penalty, segregation, and evolution and are also associated with higher levels of support for women's liberation, foreign aid, gun control, property tax, and labor unions. Factor 5 (intellect/imagination) yields eight statistically significant correlations, including a positive association between higher levels of imagination and a lack of support for astrology and the moral majority.

Overall, the results in Tables 1 and 2, while not unexpected based on previous research, are still counterintuitive. Most people would probably agree with the characterization that an outgoing, agreeable, conscientious, emotionally stable, and intellectually open person would be substantially more generous in their decisions than a withdrawn, uncaring, sloppy, emotionally unstable, and closed- minded person. Similarly, as the pejorative descriptions of political conservatism quoted earlier make clear, it has been suggested that generous people are typically liberals (those with at least modest opposition to policies such as the death penalty), but again our data provide no support for any such relationship. The lack of a substantial significant association here between personality or ideology on one hand and behavioral generosity on the other is particularly stark given that this is a controlled experimen- 


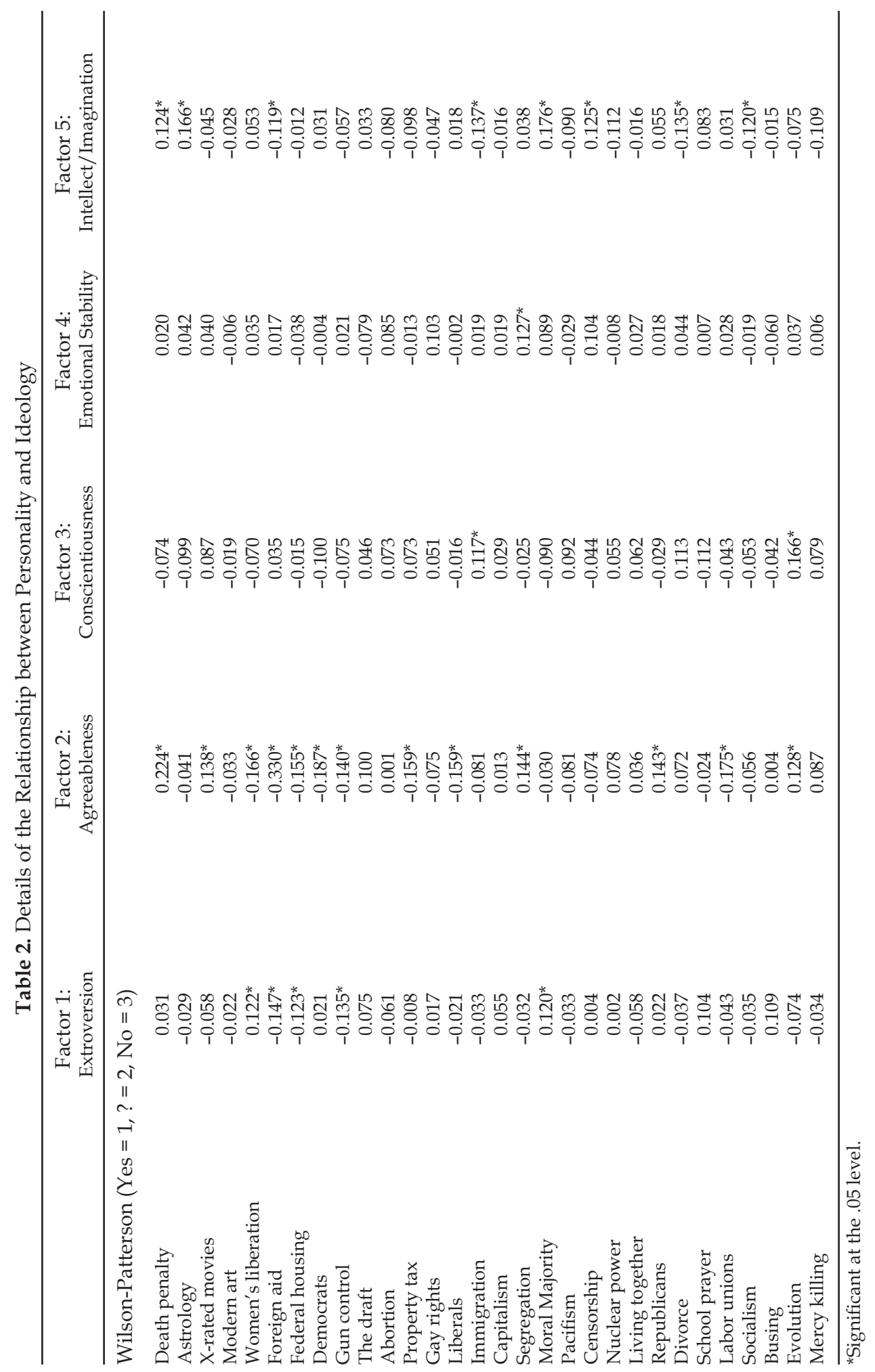


tal behavior. The failure to find clear associations between personal attitudes and behaviors in previous studies has often been attributed to the complexity of contextual impacts on individual behavior; in real-world behavior, the large array of varying contextual cues may in fact severely attenuate any relationship between personality and behavior, but here experimental control reduces both the volume and variation in context and should allow any effects to be clearly discernible.

\section{The lack of a substantial significant association \\ here between personality or ideology on one hand and behavioral generosity on the other is particularly stark given that this is a controlled experimental behavior.}

As was the case with personality and behavioral generosity, personality and ideology are only modestly related. The findings are quite similar for both selfidentified ideology and the issue-based Wilson-Patterson index (not surprising given that they are positively correlated with each other at .72). Both show a modest but statistically significant correlation with factor 2 (agreeableness) and with factor 5 (intellectual openness). As both liberals and conservatives would probably expect, agreeableness, a personality factor partially associated with the desire to please others, is more evident in liberals than in conservatives. For example, one of the items included in the agreeableness scale is "I have a soft heart," something that liberals would generally agree is a positive trait of liberals and conservatives would agree is a negative trait of liberals.

The association of liberalism with relatively high levels of self-described intellect and imagination is more contentious. Liberals will have no problem accepting the validity of this finding, but conservatives will undoubtedly be less pleased. This factor is sometimes labeled simply as openness both to reduce its association with the volatile issue of variation in intelligence and to suggest that it in fact measures openness to new experience as opposed to quality of brain power. The fact is, however, that at least in the reduced form used here, factor 5 is clearly a measure of intellect and imagination rather than openness to new experience. Items such as "I have excellent ideas," "I am quick to understand things," and "I use difficult words" clearly illustrate a focus on intellectual capability and imagination rather than simple tolerance for ambiguity. On the other hand, as these are all self-descriptions, conservatives could be forgiven for pointing out that this might reflect little more than a tendency toward self-serving intellectual pomposity among self-described liberals.

While the two positive associations are interesting, it is important not to miss the larger picture. Both of the correlations are quite weak, and there is 
no significant association for the other three facets of personality. The lack of a relationship for factor 3 (conscientiousness) is surprising. Both liberals and conservatives would probably agree that conscientiousness is a characteristic more closely tied to conservatism than to liberalism, and while the direction of the relationship is correct, the correlation is small and far short of significance. The correlation for factor 1 (extroversion) is in the negative direction, as might be expected from some of the pejorative descriptions of conservatism cited above, but again the correlation is weak and far short of statistical significance. The weakest relationship with ideology is factor 4 (emotional stability), and this places our findings clearly at odds with the previous pejorative descriptions of conservatism. Emotional stability or the lack thereof appears to be shared equally across the ideological spectrum, and we find no evidence to support the strong assertions in previous discussions that conservatives are more emotionally vulnerable than liberals.

Taken together, all of this suggests a surprisingly weak relationship between personality, interpersonal behavior, and political ideology. Neither personality nor broader political ideology offers much predictive power when applied to simple controlled experimental observation of behavioral generosity. The relationship between personality and political ideology is similarly weak.

\section{Neither personality nor broader political ideology offers much predictive power when applied to simple controlled experimental observation of behavioral generosity. The relationship between personality and political ideology is similarly weak.}

\section{Discussion}

Empirical evidence of substantial interpersonal generosity has eroded the emphasis on rational self-interested behavior in both economics and political science. These findings, consistent with our findings here (recall that retaining half of the $\$ 10$ is clearly the modal behavior in both of our experimental settings), simply cannot be explained by a model of self-interested, cognitive maximization. The attempt to account for these experimental findings has led to an explosion of concern across the social sciences and beyond for an un- 
derstanding of the evolution of cooperative social behavior in humans. If the impetus toward self-sacrificing behavior has been encoded deeply within the human brain, one might expect to find it expressed organically in fundamental variation in personality. In contrast, if socially conscious self-sacrifice is largely culturally constructed, one might expect to find it encoded in more intellectually abstract cognitive organizational structures such as ideology. Those favoring a nature-plus-nurture view would likely argue that prosocial behavior is in fact embedded interactively in both our fundamental personality and our cognitively elaborated ideologies. Despite the obvious importance of understanding the genesis of self-sacrificing behavior, little empirical work in political science has been directed at understanding the relationship between this behavior and either underlying personality traits or overarching ideological frameworks.

The findings here hold out little hope for any of these hypotheses. Deeply encoded, stable personality traits offer little predictive purchase on self-sacrificing prosocial behavior, and ideology fares no better, though as might be expected and as Mondak and Halperin (forthcoming) reported, personality seems to do much better in predicting political behaviors such as getting up to speak on a political issue. Our view as sketched above differs from the general view in several important regards. First, we view ideology as being no less deeply encoded in the genes and brains of humans than personality. Furthermore, we are not harnessed to a conception that yields clear centrality to personality as an explanatory variable on the basis of its presumed unique deep encoding. Placing both personality and something as presumably abstract as ideology abreast of each other in terms of their level of biological encoding, and hence temporal priority, allows for an alternative view of the sources of interpersonal generosity. Rather than arising from either of these deeply encoded temperaments, interpersonal generosity may arise from a conceptually distinct third deeply encoded temperament. If, as we have suggested above, each of these distinct realms of human nature originates at a similarly deep level, then there is no reason to suppose that they must be closely correlated. Some degree of overlap in the physiological systems in which they are instantiated would suggest that modest correlations may exist. This is quite different than a model that builds interpersonal behavior out of biologically encoded personality and then, in turn, builds culturally elaborated ideology out of some combination of both personality and interpersonal behavior.

\section{References}

Adorno, T., E. Frenkel-Brunswik, D. Levinson, and R. Sanford. 1950. The Authoritarian Personality. New York: Harper.

Altemeyer, Bob. 1981. Right-Wing Authoritarianism. Winnipeg, Canada: University of Manitoba Press. 1996. The Authoritarian Specter. Cambridge, MA: Harvard University Press. 
Anderson, Lisa R., Jennifer M. Mellor, and Jeffrey Milyo. 2004. Do liberals play nice? The effects of party and political ideology in public goods and trust games. Unpublished Working Paper, College of William and Mary, Williamsburg, VA.

Bachner-Melman, Rachel, Christian Dina, Ada H. Zohar, Naama Constantini, Elad Lerer, Sarah Hoch, Sarah Sella, Lubov Nemanov, Inga Gritsenko, Pesach Lichtenberg, et al. 2005. AVPR1 and SLC6A4 gene polymorphisms are associated with creative dance performance. PLoS Genetics 1:394-403.

Block, Jack, and Jeanne H. Block. 2005. Nursery school personality and political orientation two decades later. Journal of Research in Personality 39:395-422.

Boone, Christopher, Bert De Branbander, and Arjen van Witteloostuijn. 1999. The impact of personality on behavior in five Prisoner's Dilemma games. Journal of Economic Psychology 20:343-77.

Bouchard, T. J., Jr., and Matt McGue. 2003. Genetic and environmental influences on human psychological differences. Journal of Neurobiology 54:4-45.

Brandstatter, Hermann, and Werner Guth. 2002. Personality in dictator and ultimatum games. Central European Journal of Operations Research 10:191-215.

Caprara, G. V., C. Barbaranelli, and P. G. Zimbardo. 1999. Personality profiles and political parties. Political Psychology 20:175-97.

Caprara, G. V., S. Schwartz, C. Capanna, M. Vecchione, and C. Barbaranelli. 2006. Personality and politics: Values, traits, and political choice. Political Psychology 27:1-28.

Carmen, Ira. 2007. Genetic configurations of political phenomena. Annals of the American Academy of Political and Social Science 614:34-55.

Comings, D. E., R. Gade-Andavoluy, N. Gonzales, S. Wu, D. Muhleman, H. Blake, M. B. Mann, G. Dietz, G. Saucier, and J. P. MacMurray. 2000. A multivariate analysis of 59 candidate genes in personality traits: The Temperament and Character Inventory. Clinical Genetics 58:375-85.

Comrey, A. L., and J. A. Newmeyer. 1965. Measurement of radicalism-conservatism. Journal of Social Psychology 67:357-69.

De Waal, Frans B. M. 1982. Chimpanzee Politics: Power and Sex among Apes. London: Jonathan Cape.

. 1996. Good Natured: The Origins and Right and Wrong in Humans and Other Animals. Cambridge, MA: Harvard University Press.

DeYoung, Colin G., Jordan B. Peterson, and Daniel M. Higgins. 2005. Sources of openness/ intellect: Cognitive and neuropsychological correlates of the fifth factor of personality. Journal of Personality 73:825-58.

Fehr, Ernst, Urs Fischbacher, Bernhard von Rosenbladt, Jurgen Schupp, and Gert G. Wagner. 2002. A nation-wide laboratory-Examining trust and trustworthiness by integrating behavioral experiments into representative surveys. Schmollers Jahrbuch 122 (4): $519-42$.

Frank, Thomas. 2004. What's the matter with Kansas? New York: Metropolitan Books.

Jost, John T. 2006. The end of the end of ideology. American Psychologist 61:651-70.

Jost, John T., Jack Glaser, Arie W. Kruglanski, and Frank J. Sulloway. 2003. Political conservatism as motivated social cognition. Psychological Bulletin 129:339-75.

Lakoff, George. 2006. Thinking Points: Communicating our American Values and Vision. New York: Farrar, Straus, and Giroux.

McClosky, Herbert. 1958. Conservatism and personality. American Political Science Review 52:27-45. 
McCrae, Robert R., and Paul T. Costa Jr. 1999. A five-factor theory of personality. In Handbook of Personality, 2nd ed., ed. Lawrence A. Pervin and Oliver P. John. New York: Guilford.

Mehrabian, Albert. 1996. Relations among political attitudes, personality, and psychopathology. Basic and Applied Social Psychology 18:469-91.

Mestelman, Stuart, and David Feeny. 1988. Does ideology matter? Anecdotal experimental evidence on the voluntary provision of public goods. Public Choice 57:287-94.

Mondak, Jeffery J., and Karen D. Halperin. Forthcoming. A framework for the study of personality and political behavior. British Journal of Political Science.

Pratto, F., J. Sidanius, L. M. Stallworth, and B. F. Malle. 1994. Social dominance orientation: A personality variable predicting social and political attitudes. Journal of Personality and Social Psychology 67:741-63.

Ray, John J. 1985. Defective validity in the Altemeyer Authoritarianism Scale. Journal of Social Psychology 125:271-72.

Shils, Edward A. 1954. Authoritarianism: Right and left. In Studies in the Scope and Method of the Authoritarian Personality, ed. Richard Christie and Marie Jahoda. Glencoe, IL: Free Press.

Swope, Kurtis J., John Cadigan, Pamela M. Schmitt, and Robert S. Shupp. 2005. Personality preferences in laboratory economics experiments. Working Paper, Department of Economics, Ball State University, Muncie, IN.

van Gestel, S., and C. van Broeckhoven. 2003. Genetics of personality: Are we making progress? Molecular Psychiatry 8:840-52.

Whitaker, Eric. 2006. Personality and political orientation: A reanalysis of an ageold question. Unpublished paper, Department of Political Science, University of Nebraska-Lincoln. 